\title{
DAYA TERIMA KONSUMEN TERHADAP BAKPAO YANG DIPERKAYA SIFAT FUNGSIOAL SERAT DAN ANTIOKSIDAN BERBASIS DAUN KELOR (Moringa oleifera)
}

\author{
Eman Darmawan ${ }^{1}$
}

\begin{abstract}
The research was designed to determine the effect of substitution of Moringa leaves to the level of consumer acceptance of bun product and nutrient content. This research uses a completely randomized design (CRD) with single consisted Moringa leaf flour substitution $(0 \%, 5 \%, 10 \%, 15 \%, 20 \%)$, each treatment replicated 3 times. Data were analyzed using analysis of variance (ANOVA), if there was a difference between the treatment, it would analyze with Duncan's Multiple Ranges Test Method (DMRT) at the level of 5\%. The addition of Moringa leaf affect the organoleptic properties of bun product, the color of the bun was green, tasted moringa leaves, while the texture of buns increases softly. Based on organoleptic parameters, then the addition of Moringa leaves are preferred by the panelists was the addition of Moringa leaves as much as $10 \%$ with a score of 3.85, Reseda (3.3), a rather tasted the leaves of Moringa (3.35), soft texture (3.85), 36.78\% water, $0.09 \%$ chlorophyll, fiber $14.98 \%$, and $43.48 \%$ antioxidant activity.
\end{abstract}

Keywords: bun, moringa leaf, fiber, antioxidant

\begin{abstract}
ABSTRAK
Tujuan penelitian adalah untuk mengetahui pengaruh substitusi daun kelor terhadap tingkat kesukaan/penerimaan bakpao yang dihasilkan dan mengetahui kandungan gizi bakpao yang dihasilkan. Penelitian ini menggunakan Rancangan Acak Lengkap (RAL) dengan faktor tunggal yaitu pengaruh konsentrasi substitusi tepung daun kelor ( $0 \%$, $5 \%, 10 \%, 15 \%, 20 \%$ ), tiap perlakuan dilakukan pengulangan sebanyak 3 kali. Data yang diperoleh dilakukan Analisis of Varians (ANOVA), apabila terdapat perbedaan antara perlakuan dilakukan uji lanjutan dengan Metode Duncan`s Multiple Ranges Test (DMRT) pada jenjang 5\%. Penambahan daun kelor berpengaruh terhadap sifat organoleptik bakpao yang dihasilkan, warna semakin hijau, semakin terasa daun kelor, sedangkan tekstur bakpao semakin tidak empuk/lunak. Berdasarkan parameter organoleptik, maka penambahan daun kelor yang disukai oleh panelis adalah penambahan daun kelor sebanyak 10\% dengan skor 3,85, warna hijau muda $(3,3)$, agak terasa daun kelor $(3,35)$, tekstur empuk $(3,85)$, air 36,78\%, klorofil 0,09\%, serat 14,98\%, dan aktivitas antioksidan 43,48\%.
\end{abstract}

Keyword: bakpao, daun kelor, fiber, antioksidan

\section{Pendahuluan}

Kelor (Moringa oleifera) tumbuh dalam bentuk pohon, berumur panjang (perenial) dengan tinggi 7 - $12 \mathrm{~m}$. Batangberkayu (lignosus), tegak, berwarna putih kotor, kulit tipis, permukaan kasar. Percabangan simpodial, arah cabang tegak atau miring, cenderung tumbuh lurus dan memanjang. Daun kelor berbentuk bulat telur dengan ukuran kecil-kecil bersusun majemuk dalam satu tangkai. Bunganya berwarna putih kekuning-kuningan dan tudung pelepah bunganya berwarna hijau.

Di Indonesia, tanaman Kelor dikenal dengan berbagai nama. Masyarakat Sulawesi menyebutnya kero, wori, kelo, atau Keloro. Orang-orang Madura menyebutnya maronggih. Di Sunda dan Melayu disebut Kelor. Di Aceh disebut murong. Di Ternate dikenal sebagai kelo. Di Sumbawa disebut kawona.

Menurut Dudi (2015) kelor merupakan salah satu tanaman yang paling bergizi, kaya akan betakaroten $(18,9 \mathrm{mg} / 100 \mathrm{~g})$ melebihi wortel, mengandung protein $(27,1 \mathrm{~g} / 100 \mathrm{~g})$ melebih kacang polong, mengandung vitamin C (17,3 $\mathrm{mg} / 100 \mathrm{~g})$ lebih banyak dibanding jeruk, kandungan kalsiumnya (2.003 mg/100g) melebihi susu, mengandung zat besi (28,2 mg/100 g) lebih banyak dari bayam dan kandungan kaliumnya lebih banyak dari pisang.

Kelor merupakan suatu potensi yang dapat dimanfaatkan sebagai bahan baku ataupun bahan tambahan pada produk makanan sebagai upaya untuk meningkat kandungan gizi dan sifat

\footnotetext{
${ }^{1}$ Program Studi Teknologi Pangan Fakultas Teknologi Pertanian Universitas Widya Mataram Yogyakarta 凶e_dmwn@yahoo.com
} 
fungsional dari bahan makanan. Akan tetapi citarasa dan aromanya daun kelor kurang disukai oleh masyarakat. Oleh karena itu untuk mengoptimalkan penerimaan daun kelor oleh masyarakat, maka perlu mengolah daun kelor sebagai bahan makanan bakpao. Bakpao merupakan makanan yang banyak disukai oleh masyarakat, terbuat dari tepung terigu dengan penambahan bahan lain seperti : telur, margarine, gula air dan yeast/khamir.

Bakpao yang diperkaya daun kelor diharapkan dapat menjadi salah satu solusi untuk meningkatkan kualitas nilai gizi asupan bagi masyarakat karena masih sering ditemukan kasus malnutrisi dan meningkatkan sifat fungsional bakpao karena kaya akan antioksidan dan serat kasar, sehingga dapat mencegah timbulnya berbagai penyakit degeneratif (kolesterol, hipertensi, jantung, penyakit gula dan sebagainya) dan memperlancar pencernaan.

Akan tetapi karena adanya perbedaan kandungan gizi dan sifat fisik antara daun kelor dengan tepung terigu, maka penggunaan daun kelor dapat mempengaruhi kualitas dan tingkat kesukaan/penerimaan komsumen terhadap bakpao yang dihasilkan. Hal ini yang mendorong peneliti untuk meneliti optimasi pembuatan bakpao dengan variasi daun kelor terhadap mutu yang dihasilkan.

Penenlitian ini bertujuan untuk mengetahui pengaruh substitusi daun kelor terhadap tingkat kesukaan/penerimaan konsumen terhadap bakpao yang dihasilkan dan mengetahui kandungan sifat fungsional pada bakpao yang dapat diterima konsumen.

\section{Metode penelitian \\ Bahan}

Bahan yang digunakan pada penelitian ini adalah tepung terigu merek Cakra produksi PT. Bogasari, telur, air, gula bubuk, margarine, yeast merk GS Super, dan daun kelor dari Bantul serta bahan-bahan untuk analisa kimia PA produk E. Merck.

Alat yang digunakan dalam penelitian ini adalah timbangan, baskom plastik, wajan, termotemer, pengaduk, gilingan, peralatan gelas, alat destilasi, labu Kjeldal, Erlenmeyer, dan alat uji sensoris.

\section{Pembuatan tepung daun kelor}

Daun kelor dicuci terlebih dahulu dengan tujuan untuk menghilangkan kotoran-kotoran yang menempel ataupun terikut dalam daun, daun kelor bersih ditiriskan dan dilayukan dengan cara dikering-anginkan selama 1 jam, dikeringkan menggunakan alat pengering kabinet pada suhu $50^{\circ} \mathrm{C}$ selama $24 \mathrm{jam}$. Selama proses pengeringan daun kelor harus dibalik secara kontinyu, agar panas merata. Daun kelor kering selanjutnya dilakukan penepungan/penggilingan dan untuk memperoleh ukuran tepung yang seragam kemudian di saring dengan menggunakan penyaring ukuran 60 mesh.

\section{Pembuatan bakpao}

Tepung komposit (terigu dan tepung daun kelor) sesuai dengan perbandingan, yaitu (100:0\%), (95\%:5\%), (90\%:10\%), dan (85\%:15\%), (80\%:20\%) yang sudah disiapakan dicampur hingga rata (homogen), kemudian ditambahkan gula pasir dan telur serta margarine putih sampai homogen. Selanjutnay dilakukan penambahan yeast dan tepung komposit (terigu dan tepung ubi jalar), sedikit demi sedikit, sambil diaduk-aduk sampai sampai homogen. Setiap 100 gram tepung komposit ditambahkan air sebanyak $50 \mathrm{ml}$. Selanjutnya adonan didiamkan selama 15 menit. Adonan yang telah dibentuk bakpao dimasukkan ke dalam alat pengukus yang sudah dipanaskan sampai mendidih, dimasak dengan suhu $100^{\circ} \mathrm{C}$ selama 15 menit.

\section{Rancangan percobaan}

Penelitian ini dilakukan dengan metode Rancangan Acak Lengkap (RAL) yang terdiri dari 5 perlakuan. Tiap perlakuan dilakukan pengulangan sebanyak 3 kali. Data yang diperoleh dianalisa dengan Analyst of Varians (ANOVA) dan bila terdapat perbedaan antar perlakuan dilanjutkan dengan uji lanjut DMRT pada taraf signifikan 5\%.

\section{Hasil dan pembahasan \\ Uji organoleptik}


Uji organoleptik terhadap bakpao yang dihasilkan meliputi warna, rasa, tekstur dan Tabel 1. Hasil uji sensoris bakpao daun kelor

\begin{tabular}{|c|c|c|c|c|c|c|}
\hline \multirow[t]{2}{*}{ Tipe Uji Organoleptik } & \multicolumn{5}{|c|}{ Konsetrasi daun kelor (\%) } & \multirow[t]{2}{*}{ Keterangan } \\
\hline & 0 & 5 & 10 & 15 & 20 & \\
\hline $\begin{array}{l}\text { A. Scoring } \\
\text { 1. Warna }\end{array}$ & $1,3 d$ & $2,35 \mathrm{c}$ & $3,3 b$ & $4,25 \mathrm{a}$ & $4,4 \mathrm{a}$ & $\begin{array}{l}\text { 1. Kuning } \\
\text { 2. Kuning sedikit kehijauan } \\
\text { 3. Hijau muda } \\
\text { 4. Hijau } \\
\text { 5. Hijau Tua }\end{array}$ \\
\hline 2. Rasa & $2,15 \mathrm{c}$ & $2,95 b$ & $3,35 b$ & $4,56 a$ & $4,73 \mathrm{a}$ & $\begin{array}{l}\text { 1. Sangat tidak terasa daun kelor } \\
\text { 2. Tidak terasa daun kelor } \\
\text { 3. Agak terasa daun kelor } \\
\text { 4. Terasa daun kelor } \\
\text { 5. Sangat terasa daun kelor }\end{array}$ \\
\hline 3. Tekstur & $4,45 a$ & $4,2 \mathrm{a}$ & $3,65 b$ & $2,95 \mathrm{c}$ & $2,15 \mathrm{~d}$ & $\begin{array}{l}\text { 1. Sangat tidak empuk } \\
\text { 2. Tidak empuk } \\
\text { 3. Agak empuk } \\
\text { 4. Empuk } \\
\text { 5. Sangat empuk }\end{array}$ \\
\hline $\begin{array}{l}\text { B. Kesukaan } \\
\quad(\text { Hedonic scale })\end{array}$ & $4,45 \mathrm{a}$ & $4,1 \mathrm{a}$ & $3,85 b$ & $2,4 \mathrm{c}$ & $1,95 \mathrm{~d}$ & $\begin{array}{l}\text { 1. Sangat Tidak Suka } \\
\text { 2. Tidak Suka } \\
\text { 3. Agak Suka } \\
\text { 4. Suka } \\
\text { 5. Sangat Suka }\end{array}$ \\
\hline
\end{tabular}

kesukaan secara keseluruhan. Hasil uji organoleptik dapat dilihat pada Tabel 1.

Keterangan : Rerata yang diikuti huruf yang berbeda dalam baris yang sama menunjukkan antar perlakuan berbednyata pada taraf signifikansi $5 \%$.

\section{Warna}

Hasil uji statistik bakpao seperti terlihat pada Tabel 1, menunjukkan bahwa penambahan daun kelor pada pembuatan bakpao berpengaruh secara nyata terhadap warna bakpao yang dihasilkan. Semakin besar subtitusi daun kelor, maka warna bakpao yang dihasilkan berwarna hijau tua. Terbentuknya warna hijau merupakan warna pigmen klorofil yang berasal dari daun kelor.

\section{Rasa}

Rasa merupakan salah satu parameter mutu yang dapat ditangkap oleh indera perasa. Berdasarkan hasil uji rasa bakpao, bahwa semakin besar penambahan daun kelor maka rasa bakpao yang dihasilkan semakin terasa daun kelo dan ada pahitnyar. Hal ini diduga seiring dengan meningkatnya jumlah daun kelor yang ditambahkan, maka akan menyebabkan terjadinya peningkatan intensitas rasa daun kelor. Panelis mulai memberikan rasa daun kelor pada konsentrasi $5 \mathrm{~g}$.

\section{Tekstur}

Berdasarkan hasil uji statistik bakpao terhadap tekstur bakpao menunjukkan bahwa penambahan daun kelor yang semakin besar berpengaruh secara nyata terhadap bakpao yang dihasilkan. Semakin besar penambahan daun kelor akan menghasilkan bakpao yang tidak empuk/lunak. Menurut Winarno (1992) serat merupakan senyawa yang dapat mengikat air, sehingga selama pengolahan air yang terikat dengan serat tidak mudah lepas dan dampaknya tekstur menjadi tidak empuk/lunak.

\section{Kesukaan}

Bakpao dengan penambahan daun kelor yang makin besar tidak disukai oleh panelis. Hal tersebut berkaitan dengan warna, rasa dan tekstur bakpao yang dihasilkan. Atas dasar kesukaan secara keseluruhan tersebut, maka panelis menyukai bakpao penambahan daun kelor maksimal $10 \%$ dengan nilai 3,85 , warna hijau muda $(3,3)$, agak terasa daun kelor $(3,35)$, tekstur empuk $(3,85)$.

\section{Hasil Analisa Kimia Bakpao Terpilih}


Berdasarkan hasil uji organoleptik diperoleh bakpao yang disukai adalah bakpao dengan penambahan daun kelor 10\%. Bakpao yang disukai panelis selanjutnya dianalisa kimia yang meliputi analisa kadar air, kloroifl, serat kasar dan aktivitas antioksidan. Hasil analisa kimia bakpao daun kelor yang disukai dapat dilihat pada Tabel 2 .

Tabel 2. Hasil analisa kimia bakpao daun kelor yang terpilih

\begin{tabular}{lll|l}
\hline $\begin{array}{c}\text { Air } \\
(\%)\end{array}$ & $\begin{array}{c}\text { Klorofil } \\
(\% \mathrm{db})\end{array}$ & $\begin{array}{c}\text { Serat } \\
(\% \mathrm{db})\end{array}$ & $\begin{array}{c}\text { Aktivitas Antioksidan } \\
(\%)\end{array}$ \\
\hline 36,78 & 0,09 & 14,98 & 43,48 \\
\hline
\end{tabular}

Uji kadar air ini bertujuan untuk mengetahui kadar air bakpao daun kelor. Pengujian kadar air dari sampel yang ditambah daun kelor $10 \%$ didapatkan hasilnya mencapai 36,78\%. Meskipun jika dibandingakan dengan standar mutu bakpao khususnya bakpao daging, maka kadar bakpao dapat memenuhi standar bakpao karena standar mutu kadar air bakpao daging maksimal $67,0 \%$.

Penambahan daun kelor pada pembuatan bakpao berpengaruh secara nyata terhadap kadar serat bakpao yang dihasilkan. Kadar serat bakpao terpilih mencapai $14,98 \%$ db seperti terlihat pada Tabel 8. Hal ini menunjukkan bahwa bakpao daun kelor memiliki sifat fungsional serat yang bermanfaat bagi kesehatan.

Meningkatnya aktivitas antioksidan pada bakpao merupakan suatu hal yang menguntungkan bagi produk bakpao ini dikarenakan antioksidan merupakan senyawa yang bermanfaat bagi kesehatan. Secara alami zat ini sangat besar peranannya pada tubuh manusia untuk mencegah terjadinya penyakit karena dapat menekan kerusakan sel pada tubuh manusia sebagai akibat proses oksidasi radikal bebas. Seperti pada antihipertensi, pencegah gangguan fungsi hati (Kumalaningsih. 2006). Aktivitas antioksidan bakpao terpilih adalah 43,48\%.

\section{Kesimpulan}

Substtusi tepung daun kelor berpengaruh terhadap sifat organoleptik bakpao yang dihasilkan, warna semakin hijau, semakin terasa daun kelor, sedangkan tekstur bakpao semakin tidak empuk/lunak. Subtstitusi tepung daun kelor yang disukai oleh panelis adalah subtitusi tepung daun kelor sebanyak $10 \%$ dengan skor 3,85 , warna hijau muda $(3,3)$, agak terasa daun kelor $(3,35)$, tekstur empuk $(3,85)$, air 36,78\%, klorofil 0,09 $\% \mathrm{db}$, serat $14,98 \% \mathrm{db}$, dan aktivitas antioksidan $43,48 \%$

\section{Daftar pustaka}

Anonim, 1981, Pedoman Pembuatan Roti, Djambatan, Jakarta.

Anonim, 1995, Standart Nasional Indonesia, Dewan Standarisasi Nasional Indonesia, Jakarta.

Bambang Kartika, Pudji Hastuti dan Wahyu Supartono, 1988, Pedoman Uji Inderawi Bahan Pangan, PAU Pangan Gizi UGM, Yogyakarta.

Belitz, HD dan Kieffer, 1986, Structure and Function of Gluten Protein, Cereal Chemistry 63:326-341.

Bennion. M, 1980, The Science of Food, Hon, Willey and Sons, Singapure.

Bushuk, W., 1980, Wheat Production, Properties and Quality. Great Britain, CambrigdeUniversity Press.

Dudi Krisnadi, 2015, Kelor Super Nutrisi, Kelorina.Com, Blora

Indyah Sulistyo Utami, 1992, Pengolahan Roti, PAU Pangan dan Gizi, UGM, Yogyakarta.

Slamet Sudarmaji, 1984, Prosedur Analisa Untuk Bahan Makanan dan Pertanian, Liberty, Yogyakarta.

Winarno F.G, 1984, Kimia Pangan dan Gizi, PT. Gramedia Pustaka Utama, Jakarta. 